\title{
Phenomenology Study On The Formulation Of A Vision To Achieve The Future Of The University
}

\author{
Uus Mohammad Darul Fadli \\ State University of Jakarta \\ Email: uusmohammad_im07S3@mahasiswa.unj.ac.id \\ Ma'ruf Akbar \\ State University of Jakarta \\ Email: maruf.akbar@unj.ac.id

\section{Hamidah} \\ State University of Jakarta \\ Email: hamidah@unj.ac.id
}

\begin{abstract}
The purpose of this study is to analyze the process of making a vision in a private tertiary institution (PTS) in Karawang when it was founded and the prospects for achieving the vision in the next 5 to 10 years. The existence of a vision for a tertiary institution in Indonesia is a necessity, so the existence of a vision is one of the most important assessment items in tertiary accreditation. The National Accreditation Board for Higher Education (Ban-PT) established the vision as the first serial number instrument of all tertiary accreditation assessment instruments. The research method uses phenomenology which will reveal the experience of the leaders and founders of the University. The number of informants was 17 people, consisting of 8 university leaders who made the vision, and the remaining 9 people acted as validators to validate the research data, consisting of 8 program leaders and 1 external party of the university. Data were collected using interview techniques, document studies, field observations and FGDs. Data were analyzed using content analysis, frequency analysis, and SWOT matrix analysis. The results of the study indicate that at the time of its founding, the university was in a strong condition and had many opportunities while the prospect of achieving the vision in the next 5 to 10 years seemed that university performance had to be higher because it would face the challenges of higher external factors, both from national universities and from universities international high.
\end{abstract}

Keywords: Vision, University, Phenomenology, Strengths, Weaknesses, Opportunities, Threats, SWOT.

Received: 23 October 2019 ;

Accepted: 16 April 2020 ;

Publish; December 2020.

How to Cite:

Fadli, U.M.D., Akbar, M., \& Hamidah. (2020). Phenomenology Study On The Formulation Of A Vision To Achieve The Future Of The University. International Journal of Human Capital Management, 4 (2), 11-26. https://doi.org/10.21009/IJHCM.04.02.02 


\section{INTRODUCTION}

Vision and mission statements for all higher education institutions in Indonesia have become imperative, as stated in the assessment of national accreditation instruments for higher education (Ban-PT, 2018). The vision statement must refer to the challenges that must be realized in the future (Cortés-Sánchez, 2017), where the challenges of higher education are increasingly higher, globalized, can not be separated from technological developments and growth of higher education at the international level. The Minister of Research and Technology of the Republic of Indonesia explained that the development of Indonesia's higher education competitiveness is becoming more complex, requiring the qualifications and competence of lecturers, educational infrastructure, technology readiness and so on to be of higher quality (Awaliyah, G., 2018).

Many of the vision statements of tertiary institutions in Indonesia hope to be able to become one of the world-class tertiary institutions by utilizing demographic bonuses, technological developments and increasingly dynamic human relations and driven by innovation in science and technology occurring in the process of higher education (Gardiner et al, 2017), in the midst of the development of science and technology in the face of increasingly swift changes that are not easy to overcome with existing instruments today (Barber, et al, 2013).

Another challenge that must be considered in the university vision statement is the rapid development of the Industrial Revolution 4.0 which will affect various aspects of human life, characterized by a series of emerging new technologies that combine the physical, digital and biological worlds, affecting all scientific, economic disciplines, and industry, and even challenges the idea of what it means to be human. (Schwab, K., 2019).

This research tries to uncover the process of making a vision at a private university. How much the university is able to express the internal potential, opportunities and challenges of the external environment as one of the bases in making a vision to build the future it wants?

\section{LITERATURE REVIEW}

Vision and mission statements are the most commonly used strategic planning tools today, first adopted by higher education around the 1980s. Both tools are now important practices that are applied at universities throughout the world. It was further explained by CortésSánchez, (2017) that the vision was made to answer three important organizational questions, namely (1) what is the organization's business being done ?; (2) what should the organization do ?; and (3) where does the organization want to be in the future? "Collins and Porras (1991), also Jones (1960) state that vision consists of philosophical guidance that includes core goals and beliefs, and real future expectations. So that when businesses have a strong vision, it will help them predict future events, be prepared for change and innovation, dare to face the future, predict changes in customer demand, and improve employee efficiency (Yalçın, 2005).

Vision and Mission is a framework for evaluating company performance both qualitatively and quantitatively (Baetz \& Bart, 1996; Bartkus et al, 2005); Vision can also be used as a company evaluation tool or study conducted on private companies (Duygulu et al., 2016), it can also be used for public organizations (Bart \& Tabone, 1999; Hyndman \& Eden, 2000) and can also be used for organizations not government (Patel et al, 2015). Thus a Vision statement must be formulated to strengthen organizational culture, unity and loyalty among members, and to increase employee motivation. In this case, the vision statement must reflect the culture of the organization (Doğan, 2007).

Universities are the center of change, because they must be the initiators of change. The vision statements of some universities consist of sentences which aim to improve the current situation. Özdem (2011) reports the results of his research that most universities emphasize vision statements in services related to their research functions, the most frequently used is "Becoming a well-known, prominent and respected research university nationally and internationally". 
Kibuuka (2001) reports that many university vision statements refer to management's ability to build the desired future. This almost conveys the ideal conditions desired by universities (Paina and Băcilă, 2004), capturing their future perspectives by involving the institution's long-term goals, as well as the desired market position (Özdem, 2011). Vision statements contain values that represent a set of principles and beliefs that guide the way the institution aims to achieve its mission (Kuenssberg, 2011). Based on a clear vision and strong values, the university can then determine its strategic goals, which integrate the potential and resources that develop in the institution, while trying to develop competitive advantage (Paina and Băcilă, 2004).

Cortés-Sánchez (2017) conducted a study of 291 visions from various universities throughout the world and the main results showed that (1) the vision trend was towards globalization; (2) there is encouragement of all tertiary institutions in research and teaching; (3) the absence of quantitative elements; (4) and there are no similarities between the terms used by public and private universities; (5) mission statements tend to be longer than Vision statements; (6) the vision and mission of domestic universities in South America tend to be longer; then (7) public universities focus on individuals (students) while private universities focus more on the process (teaching).

There are 10 benefits proposed by David and David (2017) for companies or institutions that have a vision, namely (1) will be able to achieve clear objectives among all managers and employees; (2) provides a basis for all other strategic planning activities, including internal and external assessments, setting goals, developing strategies, choosing among alternative strategies, developing policies, building organizational structures, allocating resources, and evaluating performance; (3) provide clear directions for the company; (4) provides a focal point for all company stakeholders; (5) resolving different views among managers; (6) promotes a shared sense of hope among all managers and employees; (7) projecting a sense of value and intention to all stakeholders; (8) project an organized and motivated organization, which is worth supporting; (9) to achieve higher organizational performance; and (10) to achieve synergy between all managers and employees. Then Arifin Research Results (2017) explained that the company's vision and mission that are able to prepare for competitiveness in the future must be integrated with the development of human capital, recruitment and corporate training.

\section{RESEARCH METHOD}

The research was conducted at a new university which was established in 2014 and only began operations in 2015 after obtaining an operational permit from the Minister. The university is considered important to be investigated because in the four years of operation it has had a number of students as many as 6,694 people with growth reaching $32 \%$ per year, so that it requires good management by paying attention to the laws and meeting the standards of good tertiary education as well.

This study uses a qualitative method with a phenomenological approach that is expected to be able to explain the experience of university leaders in making a vision to be achieved in the next 5 to 10 years. Creswell (2010: 21-22) explains that phenomenology essentially plays a role in identifying human experience about a particular phenomenon. For this reason, researchers try to understand the life experiences of university leaders as a statement of the philosophy of phenomenology that requires researchers to study a number of subjects by being directly involved and relatively long in it to develop patterns and relationships of meaning (Moustakas, 1994). The informants in this study were 11 university leaders who were willing to be interviewed, consisting of 8 university leaders (rector, vice-chancellor, deans and heads of institutions) and 3 program leaders. There are 5 leaders involved directly in biasing the vision and 6 others have a role to triangulate the data that has been conveyed by the university leaders.

Data was collected in a structured interview according to the research protocol prepared. This is intended to facilitate the interview process. In addition, field studies, documentation studies and focus group discussions (FGD) were also carried out, then the data were analyzed using content analysis, descriptive analysis and SWOT matrix analysis. Data is transcribed and 
classified (coding) beforehand according to the focus of the study in reference to the research protocol.

\section{RESULT AND DISCUSSION}

\section{The Importance of Formulating a Vision}

The leaders at this research locus deem it necessary to make an institutional vision for various reasons. Rector University (Inf-1) explained that:

".... this vision is considered very important for the university, so this vision has been made since the university was founded in 2014 ... This vision has been used as a reference for universities to achieve what they want in the future, explaining what needs to be done by us ... by all lecturers, all leaders ... employees ... and also foundations ... This vision can also be used as a reference for activities, a reference to work culture, a reference for education, research, service, for all lecturers ... for the development of their education , the development of the research, also for the development of infrastructure in the future ... "

Then it was also conveyed by the Dean of the Faculty of Technology and Computer Science (Inf-4), that:

"... as new PTS, we consider that there is a need for a vision ... vision is our dream going forward ... vision explains the hope that we want to achieve in a period of time in the future, according to the stages. .. to invite lecturers, employees, foundations to be of one heart, one direction to achieve this vision ... to be the goal to be achieved together .. "

From the results of interviews with other informants, it can be summarized the reasons for the universities to make a Vision as explained in table 1.

Table 1. Reasons for Universities to Make a Vision

\begin{tabular}{llc}
\hline No & \multicolumn{1}{c}{ The Importance of Making a Vision } & $\begin{array}{c}\text { Frequency of } \\
\text { Answers }\end{array}$ \\
\hline 1). & To explain the business that is being done. & 4 \\
\hline 2). & $\begin{array}{l}\text { To explain the hopes to be achieved by the } \\
\text { University in the future. }\end{array}$ & 5 \\
\hline 3). & $\begin{array}{l}\text { To be able to explain milestones in the following } \\
\text { years. }\end{array}$ & 6 \\
\hline 4). & $\begin{array}{l}\text { To explain the obligations that must be carried out } \\
\text { by the University, so that Tridarma and its } \\
\text { supporters can be implemented well, planned and } \\
\text { arrive at the expected goals }\end{array}$ & \\
\hline 5). & $\begin{array}{l}\text { Inviting Foundations, Lecturers, Employees, and } \\
\text { students to carry out higher education with the } \\
\text { same direction, one heart, and one goal. }\end{array}$ \\
\hline 6). & $\begin{array}{l}\text { Inviting foundations, lecturers, employees, and } \\
\text { students to carry out higher education in an } \\
\text { atmosphere of one heart, one goal. }\end{array}$ \\
\hline 7). & $\begin{array}{l}\text { To build a work culture that clearly leads to the } \\
\text { goals to be achieved. }\end{array}$ \\
\hline
\end{tabular}

\section{The Basics of Formulating a Vision}

The Vice Rector for Finance (Inf-3 as one of the actors in making a vision) explained the basis for preparing the university's vision, that: 
"My experience in the time when the vision was made ... was based on the mutual understanding of the Foundation, newly formed university leaders, prospective lecturers, prospective employees agreed that the basis for making a vision for the future ..."

Furthermore, the Dean of the Faculty of Technology and Computer Science (Inf-4) stated that:

"The basis for making the University Vision is the development of higher education in Indonesia, which is getting better, higher competition in universities (especially in the era of technology) is considered to be quite high challenges, the growth of Karawang Regency from Agriculture to an industrial area (the largest in West Java), tourism potential, as well as high population growth including urban job seekers from other places who enter Karawang ".

A similar sentiment was also conveyed by the Rector University (Inf-1) that:

"The other side of the basis for making the vision for the establishment of the University in the future is the existence of ... technological developments ... yes, like information, like now the era of the industrial revolution $40 \ldots$ and it becomes a reference to make the University's vision going forward ... Also globalization ... of course globalization education .....the other side .... the consideration .... the income of the population and also the national income as the main aspects that will finance these education costs. Whether it's in the present or the future."

Furthermore, the Program Coordinator of the Legal Study Program confirmed that at the time of making the vision ... the leadership of the university considered various regulations and laws, political developments, economics, society and the development of higher education both nationally and internationally. From interviews with University leaders found variations in the answers that underlie University Leaders in preparing the Vision and Mission as described in table 2 .

Table 2. Basis for Making University Vision

\begin{tabular}{llc}
\hline No & \multicolumn{1}{c}{ Answers } & Frequency \\
\hline 1). & $\begin{array}{l}\text { The Constitution of the Republic of Indonesia of 1495, } \\
\text { where one of the objectives of the constitution or state of } \\
\text { the Republic of Indonesia is to educate the life of the } \\
\text { nation }\end{array}$ & 3 \\
\hline 2). $\quad \begin{array}{l}\text { The development of tertiary institutions in Indonesia is } \\
\text { very fast responding to the demands of the development of } \\
\text { users both at home and abroad. }\end{array}$ & 5 \\
\hline 3). $\quad$ Competition in universities in Indonesia is getting tougher & 5 \\
\hline 4). & $\begin{array}{l}\text { The National Education System Long-term Plan that leads } \\
\text { to the industrial revolution 4.0 }\end{array}$ & 3 \\
\hline 5). $\quad \begin{array}{l}\text { Karawang development direction to support the growth of } \\
\text { the industrial world, agriculture, tourism and other } \\
\text { economic sectors and unemployment. }\end{array}$ & 3 \\
\hline 6$). \quad$ Order of Law No. 12 of 2012 concerning Higher Education \\
\hline 7). $\quad \begin{array}{l}\text { Government Regulation No. } 4 \text { of 2014 concerning the } \\
\text { Organization of tertiary education and Management of } \\
\text { tertiary institutions }\end{array}$
\end{tabular}


8). $\quad$ Minister of Research and Technology Higher Education 3 Minister's Regulation 44 in 2015

\begin{tabular}{lll}
\hline 9). Standard 1 Accreditation Forms from BAN-PT & 3 \\
\hline 10). As a basis for the preparation of the University Work Plan, & 3
\end{tabular} both short-term, medium-term and long-term plans, which will then be set forth in the Campus Development Plan, Renstra and Renop.

\begin{tabular}{lll}
\hline 11$).$ & Karawang / National Population Growth & 3 \\
\hline 12). & Karawang / National Revenue Growth & 3 \\
\hline 13). & Letter of Assignment from the Foundation & 2 \\
\hline 14$).$ & Law No 20 of 2003 concerning the National Education \\
& System
\end{tabular}

3. Map of Internal and External Potential of the University when Making Vision

\section{a. Strength and Weakness Map}

From the results of interviews with university representatives, it is known that maps and components of strengths and weaknesses at the time of making the vision are then collected and recapitulated in the description in table 3 below. The lowest strength score scale 1 (not strong) and highest 5 (very Strong), while the weakness score scale lowest -5 (very weak) and highest (1) slightly weak.

Table 3: Map of University Strengths and Weaknesses When Making Vision

\begin{tabular}{ccc|lc}
\hline No & Indicator Strength & $\begin{array}{c}\text { Score } \\
\text { Strength }\end{array}$ & Indicator Weakness & $\begin{array}{c}\text { Score } \\
\text { Weakness }\end{array}$ \\
\hline (1) & Foundation Support & $\begin{array}{c}\text { Very } \\
\text { Strong (5) }\end{array}$ & $\begin{array}{l}\text { University Not yet } \\
\text { known }\end{array}$ & $\begin{array}{c}\text { Very weak } \\
(-5)\end{array}$ \\
\hline (2) & $\begin{array}{l}\text { Leadership } \\
\text { Commitment }\end{array}$ & $\begin{array}{c}\text { Very } \\
\text { Strong (5) }\end{array}$ & Lectures Not Running & $\begin{array}{c}\text { Very weak } \\
(-5)\end{array}$ \\
\hline (3) & Infrastructure & $\begin{array}{c}\text { Very } \\
\text { Strong (5) }\end{array}$ & $\begin{array}{l}\text { 90\% of lecturers do } \\
\text { not have Lecturer } \\
\text { Academic Position } \\
\text { (JAD) }\end{array}$ & $\begin{array}{l}\text { Weak (-4) } \\
\end{array}$ \\
& & Strong (4) & $\begin{array}{l}\text { Don't have a professor } \\
\text { yet }\end{array}$ & $\begin{array}{c}\text { Fairly } \\
\text { Weak (-3) }\end{array}$ \\
\hline (4) & Lecturer Quantity & Strong (4) & $\begin{array}{l}\text { Research and } \\
\text { Community Service }\end{array}$ & $\begin{array}{c}\text { Fairly } \\
\text { Weak (3) }\end{array}$ \\
\hline (5) & Internal environment & Program Not Yet & \\
& & & Running & - \\
\hline (6) & Governance Planning & Strong (4) & - & \\
\hline
\end{tabular}

\section{b. Opportunity and Threat Map}

Map of Opportunities and Challenges of the University during the preparation of the Vision described in table 4 below. The highest probability score scale 5 (very likely) lowest 1 (few opportunities), while the highest weakness score scale -1 (least threat) and lowest -5 (very threatening). 
Table 4 Map of Opportunities and Threats of Universities during Formulation of Vision

\begin{tabular}{|c|c|c|c|c|}
\hline No & Opportunity Indicator & Score & Threat Indicator & Score \\
\hline (1) & Employment & $\begin{array}{l}\text { Have a } \\
\text { chance } \\
(4)\end{array}$ & $\begin{array}{l}\text { Difficulty Finding } \\
\text { Lecturers }\end{array}$ & $\begin{array}{c}\text { Simply } \\
\text { Threatening } \\
(-3)\end{array}$ \\
\hline (2) & $\begin{array}{l}\text { Local Government } \\
\text { Support and Karawang } \\
\text { Community }\end{array}$ & $\begin{array}{l}\text { Quite } \\
\text { Opportuniti } \\
\text { es (3) }\end{array}$ & $\begin{array}{l}\text { Candidates Get } \\
\text { Student } \\
\text { Candidates }\end{array}$ & $\begin{array}{l}\text { Threaten } \\
(-4)\end{array}$ \\
\hline (3) & $\begin{array}{l}\text { Potential Student } \\
\text { Candidates }\end{array}$ & $\begin{array}{l}\text { Berpeluang } \\
\text { (4) }\end{array}$ & $\begin{array}{l}\text { There is no public } \\
\text { trust }\end{array}$ & $\begin{array}{c}\text { Simply } \\
\text { Threatening } \\
(-3)\end{array}$ \\
\hline (4) & $\begin{array}{l}\text { Re-orientation of } \\
\text { prospective students to } \\
\text { State Universities and } \\
\text { Private Universities }\end{array}$ & $\begin{array}{l}\text { Quite } \\
\text { Opportuniti } \\
\text { es (3) }\end{array}$ & Community Image & $\begin{array}{c}\text { Simply } \\
\text { Threatening } \\
(-3)\end{array}$ \\
\hline (5) & $\begin{array}{l}\text { Public Interest to Study } \\
\text { in Karawang }\end{array}$ & $\begin{array}{l}\text { Quite } \\
\text { Opportuniti } \\
\text { es (3) }\end{array}$ & - & - \\
\hline (6) & $\begin{array}{l}\text { Open Cooperation } \\
\text { Opportunities }\end{array}$ & $\begin{array}{l}\text { Quite } \\
\text { Opportuniti } \\
\text { es (3) }\end{array}$ & - & - \\
\hline (7) & $\begin{array}{l}\text { There are Masters and } \\
\text { Doctoral Scholarships }\end{array}$ & $\begin{array}{l}\text { Quite } \\
\text { Opportuniti } \\
\text { es (3) }\end{array}$ & - & - \\
\hline
\end{tabular}

To get a good strategy in implementing the work program, a SWOT matrix is then made, as explained in table 5 below. The SWOT matrix table is useful for analyzing the right strategy by comparing the two sides of internal and external conditions possessed by University. 
Table 5. University SWOT Matrix When Making a Vision

\begin{tabular}{|c|c|c|}
\hline $\begin{array}{l}\text { External and Internal } \\
\text { Indicators that are } \\
\text { considered to have a } \\
\text { role when making a } \\
\text { University Vision }\end{array}$ & $\begin{array}{l}\quad \text { POWER (S) } \\
\text { 1. Foundation Support } \\
\text { 2. Leadership } \\
\text { Commitment } \\
\text { 3. Infrastructure Tools } \\
\text { 4. Lecturer Quantity } \\
\text { 5. Internal Environment } \\
\text { 6. Governance Plan }\end{array}$ & $\begin{array}{l}\text { WEAKNESSES (W) } \\
\text { 1. Not yet known } \\
\text { 2. Academic } \\
\text { Implementation } \\
\text { 3. Functional Position } \\
\text { 4. There Is No Professor } \\
\text { 5. Implementation of } \\
\text { PPM }\end{array}$ \\
\hline $\begin{array}{l}\text { OPPORTUNITIES (O) } \\
\text { 1. Employment } \\
\text { 2. Local Government } \\
\text { Support } \\
\text { 3. Community Support } \\
\text { 4. Potential Students } \\
\text { 5. Re-orientation of PTN / } \\
\text { PTS } \\
\text { 6. Lecture Interest } \\
\text { 7. Cooperation } \\
\text { Opportunities } \\
\text { 8. External Scholarship }\end{array}$ & $\begin{array}{c}\text { SO Strategy } \\
\text { Standardization through } \\
\text { Quality Assurance. } \\
\text { Improvement of } \\
\text { infrastructure, further } \\
\text { study of lecturers and } \\
\text { students, improvement of } \\
\text { the quality of tridarma by } \\
\text { training in skills, abilities, } \\
\text { careers, welfare, } \\
\text { cooperation and } \\
\text { accreditation }\end{array}$ & $\begin{array}{c}\text { WO Strategy } \\
\text { Cooperation, mastery of } \\
\text { media promotion, } \\
\text { cooperation, improvement } \\
\text { of JAD and career of } \\
\text { lecturers, improvement of } \\
\text { skills, abilities, } \\
\text { assignments, use of } \\
\text { modern information } \\
\text { systems }\end{array}$ \\
\hline $\begin{array}{l}\quad \text { Threat (T) } \\
\text { 1. Difficulties in Finding } \\
\text { Lecturers } \\
\text { 2. Student Persangian } \\
\text { 3. Community Trust } \\
\text { 4. Community Image }\end{array}$ & $\begin{array}{c}\text { ST Strategy } \\
\text { Collaboration between } \\
\text { Higher Education and } \\
\text { Senior High School, } \\
\text { Promoting Media } \\
\text { Promotion, Use of } \\
\text { Modern Information } \\
\text { Systems }\end{array}$ & $\begin{array}{c}\text { WT Strategy } \\
\text { Cooperation, promotion, } \\
\text { Governance Reform, } \\
\text { Lecturer and Tend } \\
\text { Training, Use of Modern } \\
\text { Information Systems }\end{array}$ \\
\hline
\end{tabular}

From the SWOT Matrix table 5, there are 4 strategies that can be undertaken by the University for establishing vision, with the main strategies that can be taken are:

1) Standardization through University Quality Assurance. and accreditation

2) Improvement of University infrastructure and governance

3) Advanced studies of lecturers and students

4) Improvement of the quality of input, process and output tridarma

5) Training and guidance of skills, abilities

6) Improvement of lecturers \& Welfare academic positions

7) Use of modern information systems,

8) Promoting Media Promotion

9) Collaboration between Higher Education, High Schools, the World of Business and Government

\section{Map of University's Potential Expectations in the Next 5 to 10 Years}

To estimate the level of university ability to achieve the Vision that has been made, it is necessary to estimate the mapping of the potential strength of the next 5 to 10 years. The results of interviews with university leaders regarding expectations of internal potential and estimates of external potential in the next 5 to 10 years are shown in table 6 and table 7. 
Table 6.: Map of Internal Potential in the next 5 to 10 years

\begin{tabular}{|c|c|c|c|c|}
\hline No & Strength Indicator & Score & $\begin{array}{l}\text { Weakness } \\
\text { Indicator }\end{array}$ & Score \\
\hline (1) & Foundation Support & $\begin{array}{c}\text { Very } \\
\text { Strong (5) }\end{array}$ & \multirow{3}{*}{$\begin{array}{l}\text { (1) Motivation } \\
\text { (2) Work } \\
\text { Culture } \\
\text { (3) Modeling }\end{array}$} & $\begin{array}{c}\text { Slightly } \\
\text { weak }(-2)\end{array}$ \\
\hline (2) & $\begin{array}{l}\text { Higher Education } \\
\text { Accreditation }\end{array}$ & Strong (4) & & $\begin{array}{c}\text { Slightly } \\
\text { weak }(-2)\end{array}$ \\
\hline (3) & HR Lecturer & Strong (4) & & $\begin{array}{c}\text { Slightly } \\
\text { weak }(-2)\end{array}$ \\
\hline (4) & Education quality & Strong (4) & - & - \\
\hline (5) & $\begin{array}{l}\text { Research and } \\
\text { Community Service }\end{array}$ & Strong (4) & - & - \\
\hline (6) & Alumni Quality & Strong (4) & - & - \\
\hline$(7)$ & Brand Image & Strong (4) & - & - \\
\hline$(8)$ & Sources of funding & Strong (4) & - & - \\
\hline (9) & Information Systems & Strong (4) & - & - \\
\hline
\end{tabular}

Table 7. External Potential Maps for the Next 5-10 Years

\begin{tabular}{|c|c|c|c|c|}
\hline No & $\begin{array}{l}\text { Opportunity } \\
\text { Indicator }\end{array}$ & Score & Threat Indicator & Score \\
\hline (1) & Technology Support & $\begin{array}{l}\text { Very Chance } \\
\text { (5) }\end{array}$ & Job Competition & $\begin{array}{l}\text { Threaten (- } \\
\text { 4) }\end{array}$ \\
\hline (2) & Cooperation & $\begin{array}{l}\text { Very Chance } \\
\text { (5) }\end{array}$ & $\begin{array}{l}\text { Penetration from } \\
\text { Competitor } \\
\text { Universities }\end{array}$ & $\begin{array}{c}\text { Simply } \\
\text { Threatening } \\
(-3)\end{array}$ \\
\hline (3) & $\begin{array}{l}\text { Karawang } \\
\text { Community Income }\end{array}$ & $\begin{array}{l}\text { Opportunity } \\
\text { (4) }\end{array}$ & $\begin{array}{l}\text { Displacement of } \\
\text { Lecturers with } \\
\text { Achievements }\end{array}$ & $\begin{array}{c}\text { Simply } \\
\text { Threatening } \\
(-3)\end{array}$ \\
\hline (4) & $\begin{array}{l}\text { Policy Support from } \\
\text { the Directorate of } \\
\text { Higher Education } \\
\text { (Dikti) }\end{array}$ & $\begin{array}{l}\text { Opportunity } \\
\text { (4) }\end{array}$ & $\begin{array}{l}\text { Higher Education } \\
\text { Reputation }\end{array}$ & $\begin{array}{c}\text { Simply } \\
\text { Threatening } \\
(-3)\end{array}$ \\
\hline (5) & $\begin{array}{l}\text { Support of Higher } \\
\text { Education Service } \\
\text { Institutions (L2Dikti) }\end{array}$ & $\begin{array}{l}\text { Opportunity } \\
\text { (4) }\end{array}$ & - & - \\
\hline (6) & Employment & $\begin{array}{c}\text { Quite } \\
\text { Opportunities } \\
\text { (3) }\end{array}$ & - & - \\
\hline (7) & $\begin{array}{l}\text { Karawang Regional } \\
\text { Government Support }\end{array}$ & $\begin{array}{c}\text { Quite } \\
\text { Opportunities } \\
\text { (3) }\end{array}$ & - & - \\
\hline (8) & Competitor Factor & $\begin{array}{c}\text { Quite } \\
\text { Opportunities } \\
\text { (3) }\end{array}$ & - & - \\
\hline (9) & Scholarship & $\begin{array}{c}\text { Quite } \\
\text { Opportunities } \\
\text { (3) }\end{array}$ & - & - \\
\hline
\end{tabular}


Table 8. University SWOT Matrix in the Next 5-10 Years

\begin{tabular}{|c|c|c|}
\hline $\begin{array}{l}\text { External and internal } \\
\text { indicators that are } \\
\text { judged to play a role for } \\
\text { the University in the } \\
\text { next } 5 \text { to } 10 \text { years }\end{array}$ & $\begin{array}{l}\text { STRENGTH (S) } \\
\text { 1.Foundation Support } \\
\text { 2.Higher Education } \\
\text { Accreditation } \\
\text { 3.HR Lecturer } \\
\text { 4.Education quality } \\
\text { 5.Research and Community } \\
\text { Service } \\
\text { 6.Alumni Quality } \\
\text { 7.Brand Image } \\
\text { 8.Sources of funding } \\
\text { 9.Information Systems }\end{array}$ & $\begin{array}{l}\text { WEAKNESSES (W) } \\
\text { 1. Work Motivation } \\
\text { 2. Work Culture } \\
\text { 3. Modeling }\end{array}$ \\
\hline $\begin{array}{l}\text { OPPORTUNITIES (O) } \\
\text { 1.Technology Support } \\
\text { 2. Cooperation } \\
\text { 3. Karawang Community } \\
\text { Income } \\
\text { 4.Policy Support from the } \\
\text { Directorate of Higher } \\
\text { Education (Dikti) } \\
\text { 5.Support of Higher } \\
\text { Education Service } \\
\text { Institutions (L2Dikti) } \\
\text { 6.Employment } \\
\text { 7. Karawang Regional } \\
\text { Government Support } \\
\text { 8. Competitor Factor } \\
\text { 9. Scholarship }\end{array}$ & $\begin{array}{c}\text { SO STRATEGY } \\
\text { Improved University } \\
\text { Standards, Investment is } \\
\text { directed at the quality of } \\
\text { information systems, } \\
\text { increasing national and } \\
\text { international accreditation, } \\
\text { fostering and improving the } \\
\text { quality of lecturers and } \\
\text { students to improve } \\
\text { processes and quality of } \\
\text { output }\end{array}$ & $\begin{array}{l}\text { WO STRATEGY } \\
\text { Career guidance, } \\
\text { motivation, behavior } \\
\text { and product based on } \\
\text { teamwork to utilize the } \\
\text { modernization of } \\
\text { technology, } \\
\text { government policy and } \\
\text { reach the business } \\
\text { world and society }\end{array}$ \\
\hline $\begin{array}{l}\text { THREAT (T) } \\
\text { 1.Job Competition } \\
\text { 2.Penetration from } \\
\text { Competitor Universities } \\
\text { 3.Displacement of } \\
\text { Lecturers with } \\
\text { Achievements } \\
\text { 4.Higher Education } \\
\text { Reputation }\end{array}$ & $\begin{array}{l}\qquad \text { ST STRATEGY } \\
\text { Increasing cooperation } \\
\text { between the business world } \\
\text { and large tertiary } \\
\text { institutions / competitors to } \\
\text { reduce the transfer of } \\
\text { lecturers and increase the } \\
\text { reputation of domestic and } \\
\text { foreign universities }\end{array}$ & $\begin{array}{l}\text { WT STRATEGY } \\
\text { Improved awards and } \\
\text { recognition of lecturers } \\
\text { and work partners' } \\
\text { reputation }\end{array}$ \\
\hline
\end{tabular}

The SWOT matrix analysis presented in table 8 above makes it easy for policy makers on the strategies that can be taken by the University to face the challenges faced by exploiting opportunities and strengths and fixing weaknesses as soon as possible to take advantage of existing opportunities to realize work programs that Restra has been made for the period 20192030.

Mapped estimates in the next 5-10 years the motivation, culture and exemplary of University HR will decrease due to fatigue and possibly work boredom. For that the leaders must respond even better. Likewise, challenges from other tertiary institutions and the competition of lecturers will probably increase. For this reason, the SWOT matrix can be used as a solution to determine the attitude of the University in the next 5 to 10 years with a focus on the results of the matrix analysis strategy, which focuses on the strategic aspects as follows:

1) Improvement of Higher Education Standards and National and International Accreditation 
2) Investment is directed at the quality of information systems,

3) Guiding and improving the quality of lecturers and students to improve the process and the quality of output

4) Career guidance, motivation, behavior and product based on teamwork to take advantage of the modernization of technology, government policies and reach the business world and society

5) Increasing cooperation between the business community and large tertiary institutions / competitors to reduce the transfer of lecturers and increase the reputation of domestic and foreign universities

6) Increasing appreciation and recognition of lecturers and work partners' reputation.

\section{Vision and Mission Formulation Process}

To produce the right vision in accordance with the potential and desires of internal stakeholders, the Universiats has made three vision-making sessions, namely at the time of establishment, at the time after the issuance of the Decree of Establishment from the Minister and the last at the time the University will carry out operations. The Chancellor explained that this was done due to various considerations mainly to accommodate the advice of external parties.

The Vice Chancellor for Finance and Personnel (Inf-3) explained the process of making the University's vision, that:

"Our experience when creating a Vision at that time was by bringing in Experts, continuing to Form a Committee, conducting discussions and seminars. There were two experts brought in at that time namely (1) Prof. Gunawan from Unpar Bandung (He was also one of PT Ban's expert staff), at that time he explained about (a) Development of National, Asean and International Higher Education Institutions, higher education obligations, such as what is that, higher education, (b) what standards must be achieved by the tertiary institution; and (c) the duties of foundations, leaders, lecturers and university employees. Then (2) bring in Kopertis Coordinator Prof. Dr. Abdul Hakim Halim, he explained about (a) The development of tertiary institutions in Indonesia, West Java and Banten; and (b) explain what the task of the private university should be, be able to be competitive with other universities, even be competitive with state universities ".

The Chancellor (Inf-1) himself explained that:

"Based on experience, the way used by the leadership of the University to compile the Vision and Mission is to first bring in experts, the first we do is bring in Prof. Dr. Johanes Gunawan from the Parahiyangan Catholic University in Bandung, then brought in the Coordinator of the Private Higher Education (Kopertis) at the time (Prof. Dr. Abdul Hakim Halim), then we conducted a seminar team composing vision and mission, discussion, namely through FGD ".

Regarding the process of formulating the Vision, the Chairperson of the Program of Psychology Studies Program (Inf-8) said that:

"I know ... that the Universiats have brought experts in the making of a vision ... but before forming the Committee first, where the committee would later discuss, carry out a series of activities or events related to the formulation of the vision and mission. One of the agenda is in the form of a seminar by bringing experts, namely Prof. Yohanes Gunawan from Unpar and he was one of the assessors of PT Tires ... in 2015 (if I'm not mistaken, I forgot about the month) .... He explained about the Development national, Asean and international tertiary institutions, the existence of higher education Obligations, then the Standards that must be achieved by tertiary institutions, Foundation Tasks, Leaders, Lecturers and employees regarding if not wrong regarding the governance of tertiary 
institutions / .... then later .. .. brought in 21015 again brought Kopertis Coordinator at the time, Prof. Dr. Abdul Halim Hakim, ............ he explained the development of tertiary institutions in Indonesia especially in West Java ... and many more ... were then formulated and the results presented to the chancellor and foundation for discussion Furthermore".

The results of the document observations were recorded in the University Institution Accreditation Form 2018 page 4, that the process of making universities was carried out as many as 3 periods of formulation and the results of the final formulation agreed upon by the university's vision was "Becoming a Competitive University with International Insight"

\section{Vision Achievement Indicators}

From the results of focus group discussions (FGD), the main indicators of university vision achievement can be summarized, namely the achievement of institution and study program accreditation, lecturer intellectual capital quality, tridharma quality, graduate success and good assessment from stakeholders.

1) Accreditation of institutions and study programs

It was said by the Chancellor (Inf-1) that the achievement of the vision on the indicator of the highest competitive advantage when the University can achieve superior accreditation from the National Accreditation Agency for Higher Education (BAN-PT). The Chancellor hopes that in 2030 the university will have received superior accreditation for Higher Education Institution Accreditation (AIPT), then at least 5 study programs at the university will also get superior accreditation.

2) The quality of lecturer intellectual capital

To get a national competitive advantage is inseparable from the role of permanent lecturers as well as non-permanent lecturers at this university. It was agreed in the FGD that the indicator of excellence in intellectual capital quality is the main trigger to achieve the vision that has been set, therefore the university sets the intellectual capital quality standard for university lecturers at least the same as the performance indicator standards written in Regulation_BAN-PT Number 59 of 2018 concerning Accreditation Instruments Higher Education and BAN-PT Regulation Number 2 of 2019 concerning Study Program Accreditation Instruments. It is expected that in 2030 the number of lecturers with Doctoral degrees will be as much as 40 percent, and in each study program there are already at least 1 (one) professor.

\section{3) Tridharma quality}

Indicators of competitive advantage in the field of tridharma in 2030 are characterized by the use of information technology in various educational, research and service activities. The University expects $90 \%$ of lecturers to use renewable education information technology (following the era of the industrial revolution 4.0) in the planning, process and assessment of learning, conducting research and service, using research results and dedication to the development of learning. Collaboration between universities, government, business world and the community in supporting the process, use of results and outline of tertiary institutions has met the target of BAN-PT accreditation instruments.

\section{4) Success of graduates}

The success of graduates is an indicator of the achievement of the university's vision because graduates are genuine products from tertiary institutions. The main indicator of the success of graduates is the average waiting time to get the first job after they graduate. The university's target for graduates to wait is less than 3 months. This possibility is considered very high after considering the extent of employment in the Karawang regency. The other side of the current condition of students is student status of student identity in the university 
database, more than $40 \%$ of students are working in various national and multi-national companies spread across industrial areas around Karawang, Bekasi and Purwakarta, not including students who open own business as entrepreneurs in various fields of business.

\section{5) Stakeholder assessment}

Stakeholder assessment of the existence of the university as a whole both in the implementation of Tridarma and its supporting aspects is expected to be in the position as planned. Assessment indicators are based on general standards that exist in society and apply nationally and internationally, namely the assessment of Webometrics. Webometrics is a tool or system to measure or provide an assessment of the progress of all the best universities or universities in the world (World Class University) through the university's Website (Wikipedia).

One of the targets of achieving the university's vision is the expected Webometrics position in 2030:

a. entered in the 50 large tertiary institutions in West Java,

b. included in the category of the 500 best universities at the National level,

c. included in the category of 5000 best universities in the ASEAN level.

d. included in the category of 10,000 best universities of international level.

\section{Vision Achievement Policy}

From the results of interviews and literature studies it is known that in order to realize the vision of the university, the leaders of the University have made several guidelines, guidelines and regulations that are expected to be able to become a guideline for all leaders and foundations to realize their vision. Rules, guidelines and guidelines for achieving the written vision in the document:

1) Statute of 2014 and the last revision of 2016

2) Staffing Guidelines for 2014 and the latest revision in 2017

3) Campus Development Master Plan (RIP) in 2015

4) Stratetgis Plan (Renstra) 2015-2019

5) Operational Plan (Renop) for 2015-2019

6) Academic Regulations 2015, the last revision of 2018

7) Student Regulations of 2017

8) Guidelines for Research and Community Service of 2017

9) Academic and non-Academic Quality Standards

Campus Development Master Plan (RIP) (2015: 16-18) explains that to realize the longterm Vision, universities have made Campus Development Master Plans in 2 (two) Milestones, namely (1) Milestones of Period I (2015-2030) : Competitive, international outlook; and (2) Milestones of Period II (2031-2046): Competitive in international reputation.

Milestones of the First Period 2015-2030 are divided into 4 (four) Leadership periods (4 years each) with milestones as described below.

1. Period of 2015-2018 : Strengthening Higher Education Governance and categorized as 50 best universities in West Java

2. Period of 2019-2022 : Preparing for Competitiveness at 500 Best National Universities

3. Period of 2023-2026 : Preparing for Competitive in 5000 of the best PT in ASEAN

4. Period of 2027-2030 : Preparing for Competitive in 10000 International PT 


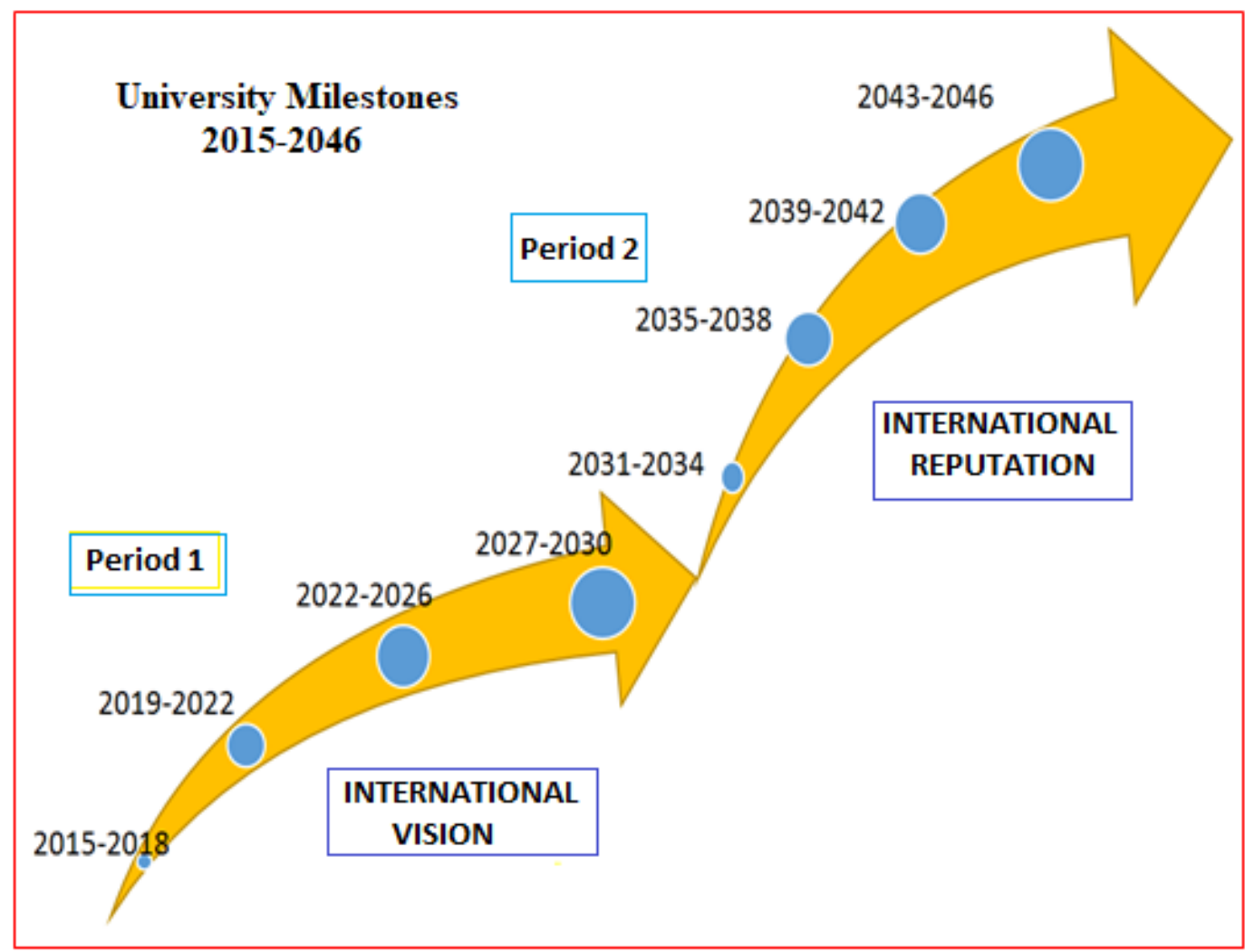

Figure 1: University Milestones of 2015-2046

Source: RIP UBP Karawang (2015: 17)

In order to achieve the milestones of the University Campus Development Master Plan, the university's general policy is to:

a. Institutional Strengthening and Development

b. HR Strengthening and Development

c. Strengthening and developing Tridarma and the work of universities

d. Strengthening and developing cooperation with various universities, government agencies, business / industry and other stakeholders, at regional, national to international levels.

\section{CONCLUSION AND RECOMMENDATION}

The results of this study explain that the university has 3 (three) times revised the making of the vision, namely the first period at the time of the establishment of the college, the second review after receiving an operational permit decree from the Minister of Education and Culture of the Republic of Indonesia and the third when the university will operate after first conduct a series of studies involving internal, external stakeholders, users and experts who are considered experts in the presentation of the university's vision.

The university's vision is complemented by clear vision achievement indicators, namely (1) Institutional accreditation and study programs; (2) The quality of intellectual capital of lecturers; (3) Quality of tridharma; (4) Success of graduates; and (5) stakeholder assessment which can be seen from the webometric position included in the 50 large tertiary institutions in West Java, the category of 1000 best national level universities, the category of 5,000 best universities of ASEAN level and included in the category of 10,000 best universities of international level.

To be able to achieve the vision that has been set, the university has made a clear policy documented in the Statute, Staffing Manual, Campus Development Master Plan, Strategic Plan, Operational Plan (Renop), Academic Regulations, Student Regulations, Research Guidelines and Community Service, Standards Academic and non-Academic Quality and various other supporting documents. Then the stages of achievement until 2030 are divided into 4 stages of achievement, each 4 (four) years according to the period of university leadership. 


\section{REFERENCES}

Arifin, AL (2017). Strategi Pengembangan Modal Manusia PT Kimia Farma (Persero) Tbk. International Journal of Human CapitalManagement. Vol. 2, No.2, December 2017, p. 153-162.

Awaliyah, G. (2018) Tantangan Perguruan Tinggi Menurut Menristekdikti. Republika.Com, Senin 07 May 2018 17:40 WIB. https://www. republika.co.id/zberita/pendidikan/duniakampus/18/06/07/p8ctn4335-ini-tantangan-perguruan-tinggi-menurut-menristekdikti

Baetz M. and Bart C. (1996). Developing mission statements which work. Long Range Planning 29(4): 526-533.

Ban-PT (2018). Peraturan Badan Akreditasi Nasional Pendidikan Tinggi RI Nomor 59 Tahun 2018 tentang Panduan Penyusunan Laporan Evaluasi Diri, Panduan Penyusunan Laporan Kinerja Perguruan Tinggi, dan Matriks Penilaian dalam Instrumen Akreditasi Perguruan Tinggi.

Barber, Michael, Katelyn Donnelly, dan Saad Rizvi. 2013. "An Avalanche Is Coming. Higher Education and The Revolution Ahead". Voprosy Obrazovaniya/Educational Studies. Moscow, no. 3: 152-229. doi:10.17323/1814-9545-2013-3-152-229.

Bart C. (2001a). Exploring the application of mission statements on the World Wide Web. Internet Research 11(4): 360-369.

Bart C. and Tabone J. (1999). Mission statement content and hospital performance in the Canadian not-for-profit health care sector. Health Care Management Review 24(3): 1829.

Bartkus B., Glassman M. and McAfee B. (2005). Mission statement quality and financial performance. European Management Journal 24(1): 86-94.

Collins J. and Porras J. (1991). Organizational vision and visionary organizations. California Management Review 34: 30-52.

Cortés-Sánchez, J.D. 2017. Mission and Vision Statements of Universities Worldwide - A Content Analysis. Universidad del Rosario. Facultad de Administración. 152, ISSNe: 2463-1892. September 2017

Creswell, J.W. (2010). Research Design: Qualitative, Quatitative, and Mixed Methods Approaches. (California, Sage Publication, 2009, Edisi terjelamahan Tahun 2010, halaman 21-22)

David Fred R, David Forest R. 2017. Strategic Management: A Competitive Advantage Approach, Concepts and Cases, 16th Edition. Published by Pearson Education ( $) 2017$.

Doğan, B. (2007). Stratejik yönetim alanında vizyon kavramının içeriği üzerine bir çalışma. Marmara Üniversitesi Sosyal Bilimler Enstitüsü Dergisi, 7 (27), 37-47.

Duygulu W., Ozeren E., Isildar P. and Apolloni A. (2016). The sustainable strategy for small and medium sized enterprises: the relationship between mission statements and performance. Sustainability 8(7): 698.

Gardiner, M.O, Rahayu, S.I, Abdullah, M.A., Effendi, S., Darma, Y., Dartanto, T., Aruan, C.T (2017). Era Disrupsi: Peluang Dan Tantangan Pendidikan Tinggi Indonesia. Jakarta. Akademi Ilmu Pengetahuan Indonesia.

Hyndman N. and Eden R. (2000). A study of the coordination of mission, objectives and target in UK executive agencies. Management Accounting Research 11(2): 175-191.

Jones M. (1960). Evolving a Business Philosophy. Academy of Management Journal 3(2): 93 98.

Kibuuka, H. E. (2001) "Vision and Mission Statement in Christian Higher Educational Management in Eastern Africa", Journal of Research on Christian Education, Vol. 10, No. 1, pp. 87-114.

Kuenssberg, S. (2011) "The discourse of self-presentation in Scottish university mission statements", Quality in Higher Education, Vol. 17, No. 3, pp. 279-298.

Moustakas, C. (1994). Phenomenological Research Methods. (California, Sage Publication, 1994, dalam Creswell, J.W. 2009) 
Özdem, G. (2011) “An Analysis of the Mission and Vision Statements on the Strategic Plans of Higher Education Institutions", Educational Sciences: Theory and Practice, Vol. 11, No. 4, pp. 1887-1894.

Paina, N. and Băcilă, M. F. (2004) Piața educaţională - Locul universităţii, Tribuna economică, Vol. 15, No. 29, pp. 64-66.

Patel B. Booker L., Ramos H. and Bart C. (2015). Mission statements and performance in nonprofit organizations. Corporate Governance 15(5): 759-774.

Schwab, K. (2019). The Fourth Industrial Revolution. https://www.weforum.org/ about/thefourth-industrial-revolution-by-Klaus schwab. (C) 2019 World Economic Forum.

UBP Karawang (2015). Rencana Induk Pengembangan Kampus (RIP) Universitas Buana Perjuangan Karawang. Halaman 15.

Yalçın, İ. (2005). Küçük ve orta ölçekli işletmelerde yeniden yapılanma stratejileri. Ankara: Nobel Yayinevi.

Zel, U. (1997). Harekete geçirici liderlik ve işe yönelik liderlik. Ankara: MPM Yayını. 